\title{
A case of Pott's puffy tumour from primary dental infection
}

\author{
Thomas Geyton, Arthur Henderson, James Morris, Steve McDonald
}

Royal United Hospital Bath NHS Trust, Bath, UK

\section{Correspondence to \\ Dr Thomas Geyton,}

Geyton@gmail.com

Accepted 18 September 2017

\section{DESCRIPTION}

A 45-year-old man presented to the emergency department with a large midline swelling of his forehead (figures 1 and 2). He described 8 months of progressive symptoms starting with anosmia and left-sided nasal discharge. The lump on his head had appeared suddenly 2 weeks prior to presentation and continued to grow before becoming tender.

Nasendoscopy confirmed extensive left-sided polyps and discharge. A CT scan demonstrated extensive opacification of the left maxillary, sphenoid and ethmoidal sinuses with an $11 \mathrm{~mm}$ midline defect in the anterior wall of the frontal sinus at the site of the external mass. The posterior wall was very thin but intact. There was no evidence of intracranial extension.

He was taken to theatre urgently and underwent endoscopic sinus surgery with external drainage of frontal sinus abscess and polypectomy. The patient was noted to have poor dentition, so an orthopantogram was arranged. He was found to have a retained root of L7 requiring removal which was thought to be the cause of his sinusitis and subsequent Pott's puffy tumour.

Sir Percival Pott first described the Pott's puffy tumour in 1760. It is a non-neoplastic complication of acute frontal sinusitis characterised by subperiosteal abscess formation and osteomyelitis. ${ }^{1}$ CT scanning clearly demonstrates the bony anatomy of the sinuses; however, MRI is the modality of choice for demonstrating intracranial complications or for post-treatment surveillance when required. ${ }^{2}$ Pott's puffy tumour is exceptionally rare in the antibiotic

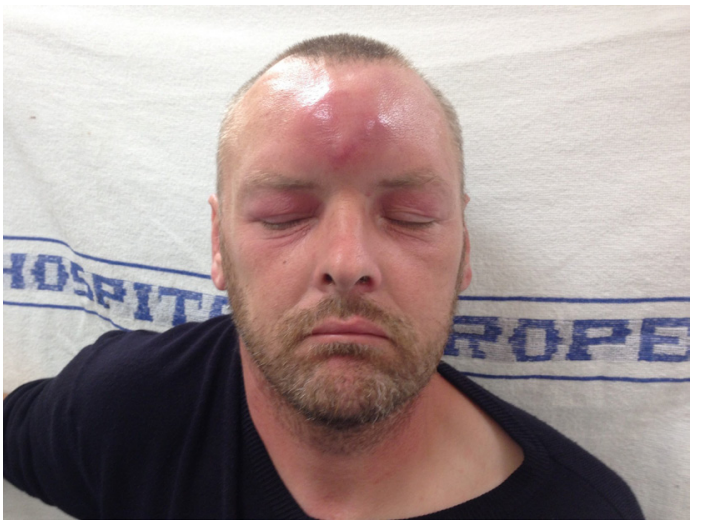

Figure 1 Initial clinical appearance of midline forehead lump measuring $8 \mathrm{~cm} \times 8 \mathrm{~cm}$.

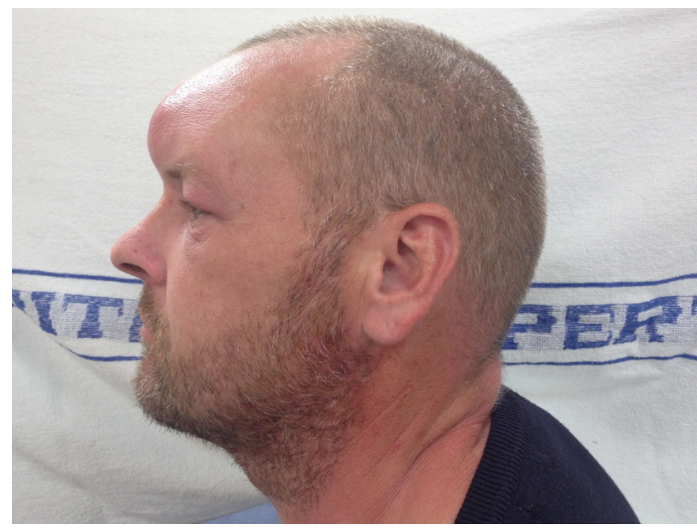

Figure 2 Lateral view of initial clinical appearance.

age with only a handful of cases reported. Treatment consists of surgical drainage and antibiotic therapy.

\section{Learning points}

- Pott's puffy tumour is a rare but serious complication of sinusitis which can be associated with intracranial complications.

- In cases of sinusitis, particularly unilateral, dentition should be examined to exclude a potential source of infection.

- CT scanning clearly delineates sinus pathology. However, where intracranial complication is suspected, MRI is the modality of choice. MRI may further be used to reduce radiation dose when post-treatment repeat imaging is indicated. $^{2}$

Contributors TG received the referral and clerked the patient as well as wrote the manuscript. AH provided extensive support in clinical care and revisions of the manuscript. JM provided support with revisions and was involved in the operation. SMD was the on-call consultant who also helped revise the manuscript and was the operating surgeon.

Competing interests None declared.

Patient consent Obtained.

Provenance and peer review Not commissioned; externally peer reviewed.

(c) BMJ Publishing Group Ltd (unless otherwise stated in the text of the article) 2017. All rights reserved. No commercial use is permitted unless otherwise expressly granted.

\section{REFERENCES}

Karaman E, Hacizade Y, Isildak H, et al. Pott's puffy tumor. J Craniofac Surg 2008;19:1694-7.

2 Sharma P, Sharma S, Gupta N, et al. Pott puffy tumor. Proc 2017:30:179-81. 
Copyright 2017 BMJ Publishing Group. All rights reserved. For permission to reuse any of this content visit http://group.bmj.com/group/rights-licensing/permissions.

BMJ Case Report Fellows may re-use this article for personal use and teaching without any further permission.

Become a Fellow of BMJ Case Reports today and you can:

- Submit as many cases as you like

- Enjoy fast sympathetic peer review and rapid publication of accepted articles

Access all the published articles

- Re-use any of the published material for personal use and teaching without further permission

For information on Institutional Fellowships contact consortiasales@bmjgroup.com

Visit casereports.bmj.com for more articles like this and to become a Fellow 